\title{
Serum Levels of Selenium, Zinc, Copper, Manganese, and Iron in Prostate Cancer Patients
}

\author{
Saleh A.K. Saleh ${ }^{a} \quad$ Heba M. Adly ${ }^{a} \quad$ Altaf A. Abdelkhaliq ${ }^{a} \quad$ Anmar M. Nassir ${ }^{b}$ \\ aBiochemistry Department; ' Department of Surgery, Faculty of Medicine, Umm Al-Qura University, Mecca, Saudi Arabia
}

\section{Key Words}

Trace elements $•$ Prostate cancer $•$ Saudi Arabia

\begin{abstract}
Backgrounds: Variations of trace element contents may be associated with several diseases including metabolic disorders, cellular growth disturbance, mutation and tumorigenesis. Prostate cancer is the second most common male cancer worldwide and stand fifth most common male cancer in Saudi Arabia. Objective: In the present study, Serum levels of selenium, zinc, copper, manganese, and iron were measured in patients with $\mathrm{BPH}$ and prostate cancer aiming to explore the association between these elements and prostate cancer. Patients and Methods: The study included 40 newly diagnosed prostate cancer patients, 22 patients with BPH and 30 healthy male subjects. All participant groups had similar socio-economic levels. Fasting blood samples were collected from all subjects and before any intervention for the patients. Serum PSA concentrations were analyzed by ELIZA and trace elements $\mathrm{Se}, \mathrm{Zn}, \mathrm{Cu}, \mathrm{Mn}$ and Fe were measured by ICP-MS. Results: Serum Se, Zn, and Mn levels of prostate cancer patients were significantly decreased compared to control groups. The levels of serum $\mathrm{Cu}$ and Fe were significantly higher in prostate cancer patients than in control groups. Conclusion: In the present study, an association
\end{abstract}

\section{KARGER}

Fax +4161306 1234

E-Mail karger@karger.com

www.karger.com
(C) 2020 The Author(s)

Open access

This article is licensed under the Creative Commons AttributionNonCommercial-NoDerivatives 4.0 International License (CC BYNC-ND) (http://www.karger.com/Services/OpenAccessLicense) Usage and distribution for commercial purposes as well as any distribution of modified material requires written permission. was noticed between serum trace elements disturbance and prostate cancer. The decreased levels of $\mathrm{Se}, \mathrm{Zn}$, and $\mathrm{Mn}$, and increased $\mathrm{Cu}$ and Fe levels may play significant roles in the initiation of prostate cancer. However, future prospective studies on the causes of trace elements alteration in prostate cancer patients are needed as well as to illustrate the relation between different prostate cancer stages and trace elements concentrations.

(c) 2020 The Author(s)

Published by S. Karger AG, Basel

\section{Introduction}

Prostate cancer $(\mathrm{PCa})$ is the second prevalent male cancer worldwide, with approximately 1.3 million annual new cases, and it also stands the fifth most common male cancer in Saudi Arabia [1, 2]. Although PCa is not the most male cancer type in Middle East region, the prediction of its future incidence and mortality burden has been more dramatic in this area of the world. Based on GLOBOCAN 2018 data and statistics from the International Agency for Research on Cancer, by 2025 the new PCa cases in the Middle East is expected to increase by $24 \%$ in Jordan, Egypt 27\%, Saudi Arabia 59\%, Bahrain 72\%, Kuwait 79\%, UAE 104\%, and Qatar 114\%

Saleh A. K. Saleh

Biochemistry Department, Faculty of Medicine

Umm Al-Qura University

715 Makkah

SA-21955 Mecca (Saudi Arabia)

E-Mail Saleh-A-S@hotmail.com 
[3]. Hence, there is an increased attention to the prospective factors that influence the incidence of this disease. Benign prostatic hyperplasia (BPH) is a benign enlargement that may require medical or surgical intervention to mitigate obstruction of urine flow. However, PCa is a life-threatening malignant tumor with serious morbidity and mortality because of the stress of tumor burden and metastatic capacity [4].

Epidemiological studies led to the hypothesis that environmental factors enhance the progression of latent PCa to a clinical disease. In this context, the pattern of lifestyle is accused of contributing to this remarkable process. Reasonable factors discussed are food, alcohol, smoking, sexual behavior, exposure to ultraviolet radiation and environmental pollution [5]. The dietary pattern in the Arab region has changed over the years due to urbanization and shifting to a more Western lifestyle [6]. Therefore, the Arab region's diet changed from one rich in antioxidants, polyunsaturated fat, and low-fat content, to a high consumption of saturated fat, junk and refined foods. A decrease of fruit, vegetable and fibers intake is clear as well. Maintaining a diet rich in antioxidants, polyunsaturated fat, and low-fat content has a credible effect against the development of many cancers [7].

The roles of trace elements in metabolic pathways were studied and have led to a good understanding of their mode of action and why they are essential to life and wellness. Trace elements augment the immune system mechanism and many studies demonstrated that deficiency or excess of trace elements can induce metabolic disorders, cellular growth disturbance, mutation, and tumorigenesis [8]. Any alterations in the trace element ion contents may impact the activity of the antioxidant enzymes [9]. Some of the environmental trace elements including selenium $(\mathrm{Se})$, zinc $(\mathrm{Zn})$, copper $(\mathrm{Cu})$, manganese $(\mathrm{Mn})$ and iron $(\mathrm{Fe})$ have been emerged in the literature in relation to various type of cancers. In these malignancies, it has been reported that serious variations occurred in the normal distribution of these elements [10].

Se and $\mathrm{Zn}$ have been reported a linkage to PCa [11]. Se has been thought to play a role in prohibition of cancer development through reduction of oxidative stress, inflammation, enhancement of immune response, induction of apoptosis and transactivation of DNA repair genes [12]. Epidemiologic studies showed a reverse correlation between serum Se levels and prostate, lung and colorectal cancers [13]. Moreover, studies have shown increased levels of $\mathrm{Cu}$ and $\mathrm{Cu} / \mathrm{Zn}$ ratio in breast, prostate and liver cancers. In addition, $\mathrm{Cu} / \mathrm{Zn}$ ratio was used for evaluation and assessment of prognosis in cancer patients [14]. It has been proven the success of $\mathrm{Zn}$ supplement in protection from free radical damage [15]. Other reports revealed that the level of $\mathrm{Zn}$ decreased in patients with some malignancies, as hepatocellular carcinoma and $\mathrm{PCa}$ [16].

Fe is an essential element contributed in many biological processes such as electron transport, ATP production and DNA synthesis [17]. However, high tissue Fe was reported in tissues surrounding the tumor and it was suggested that increased Fe content is associated with adverse effects by induced oxidative stress [18].

In the present study, serum levels of $\mathrm{Se}, \mathrm{Zn}, \mathrm{Cu}, \mathrm{Mn}$, and $\mathrm{Fe}$ were measured in patients with $\mathrm{BPH}$ and $\mathrm{PCa}$ aiming to explore the association between these elements and $\mathrm{PCa}$.

\section{Materials and Methods}

The study included 40 newly diagnosed PCa patients (mean age $68.2 \pm 5.2$ years), $22 \mathrm{BPH}$ patients (mean age $67.3 \pm 6.4$ years) and 30 healthy male subjects (mean age $65.8 \pm 6.8$ years). They were randomly selected among the volunteers who did not have any diseases, alcohol or drug addictions. Demographic data and medical history were recorded for all participants. All participant groups had similar socio-economic status. PCa patients were newly diagnosed, and the blood samples were collected before any intervention for both $\mathrm{BPH}$ and $\mathrm{PCa}$ patients. PCa patients were subjected to digital rectal examination, trans-rectal ultrasonography-guided biopsy and histopathological examination. Therefore, their PCa stages were confirmed. BPH and healthy individuals (n =52) were grouped as control group. Participants who were on trace elements supplementation for the last 3 months were precluded from the study.

\section{Blood Analysis}

Fasting blood samples were drawn and let to clot, then centrifuged for 10 minutes at 3,000 rpm and sera were separated and stored at $-20^{\circ} \mathrm{C}$ till analyzed.

Total Prostate Specific Antigen (PSA) Analysis

Serum total PSA was analyzed in sera of studied groups using chemiluminescence ELISA assay (DPC, USA).

Trace Elements Analysis

In the test, $2 \mathrm{ml}$ of $\mathrm{HNO}_{3} / \mathrm{H}_{2} \mathrm{O}_{2}$ mixture (2:1) was added to each $0.7 \mathrm{~g}$ of serum samples. The mixture tubes were incubated in a water bath for 30 minutes at $70 \mathrm{C}$ occasionally stirring and 1 $\mathrm{ml}$ of $\mathrm{HNO}_{3} / \mathrm{H}_{2} \mathrm{O}_{2}$ mixture $(2: 1)$ was added to each tube. The mixture was transferred into a Teflon vessel bomb for the microwave oven. Microwave was applied for 3 minutes at $450 \mathrm{~W}$ followed by addition of $0.5 \mathrm{ml}$ of $\mathrm{HNO}_{3} / \mathrm{H}_{2} \mathrm{O}_{2}$ mixture $(2: 1)$. The radiation was reapplied for 3 minutes and let the vessel bombs to cool down for 5 minutes and then $2 \mathrm{ml}$ of $0.1 \mathrm{~mol} / \mathrm{HNO}_{3}$ was added, followed by centrifugation for 10 minutes. The clear supernatant was 
Table 1. Serum PSA and trace elements concentrations in study population (mean \pm SD)

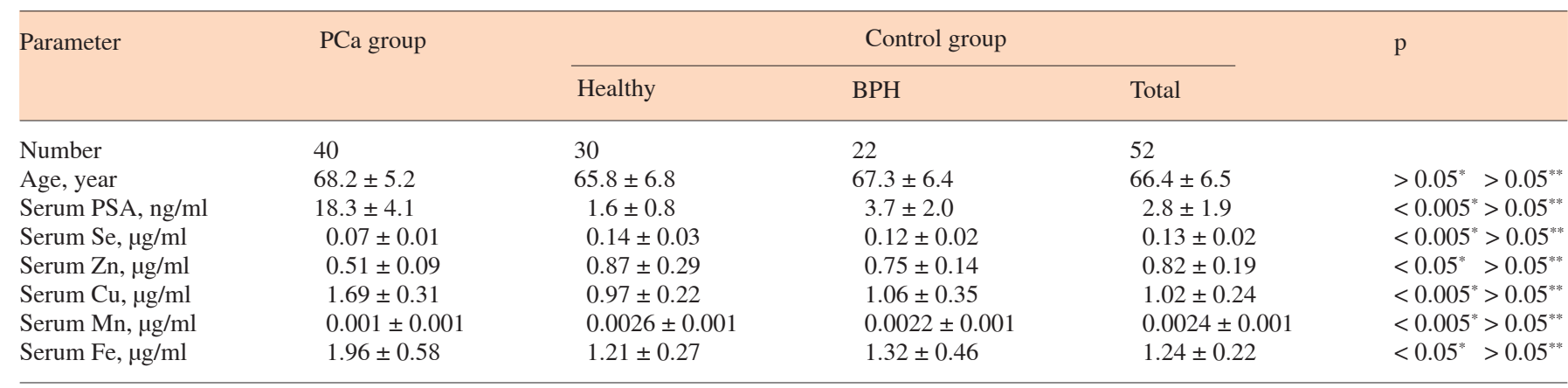

"Difference between PCa and control group; ${ }^{* *}$ Difference between BPH and healthy group.

transferred to a clean glass tube used to measure the trace elements concentrations. Serum trace elements $\mathrm{Se}, \mathrm{Zn}, \mathrm{Cu}, \mathrm{Mn}$ and Fe concentrations were analyzed by ICP-MS (Perkin Elmer 7300, Perkin-Elmer Norwalk, USA).

\section{Statistical Analysis}

Serum PSA and trace elements concentrations were expressed as arithmetic mean value in $\mu \mathrm{g} / \mathrm{ml}$ with standard deviation (SD). Data between the groups was compared and the statistical significance of mean values was determined by applying independent sample $t$-test and Mann-Whitney test. The level of significance was set at $\mathrm{p}$ value of $<0.05$.

\section{Ethical Considerations}

This study was agreed by the research committee at Faculty of Medicine, Umm Al-Qura University. An informed consent was obtained from all patients and healthy subjects. The aim of the study and the procedures that would be required from them were clear as well. All subjects were informed that they could discontinue their participation in the study, without any effect on the medical care being given to them concerning treatment and follow-up.

\section{Results}

Table 1 represents studied parameters indicating that there was no statistical difference between age of $\mathrm{PCa}$ patients and control groups $(\mathrm{p}>0.05)$. No statistical difference was found between BPH and healthy groups regarding to age and other measured parameters $(\mathrm{p}>0.05)$. Serum PSA concentrations were significantly increased in PCa patients compared to BPH and healthy subjects ( $\mathrm{p}$ $<0.05$ ) (fig. 1). Mean serum Se, $\mathrm{Zn}$ and Mn levels of PCa group were significantly lower as compared to BPH and healthy groups $(\mathrm{p}<0.005)$ (fig. $2-4)$, whereas the mean levels of serum $\mathrm{Cu}$ and $\mathrm{Fe}$ were significantly higher in PCa patients than BPH and healthy subjects $(\mathrm{p}<0.005)$ (fig. 4).

\section{Discussion}

The incidence of PCa tends to increase in the Arab region as well as Saudi Arabia, where it doubled about 8-fold between 1990 and 2016 [19]. The expected incidence by 2025 and 2040 in the Arab region may highlight the need of more attention to the risk factors that influence the prevalence of this disease [3]. Many biological and environmental risk factors are related to increased peril of PCa. These factors include diet, micronutrients and vitamins intake, genetics, smoking, alcohol consumption, physical activity, and obesity [20, 21]. Additionally, many dietary constituents may play significant roles in initiation and progression of the tumor [22]. Trace elements are important components of biological systems, they play many roles as structural materials, and are involved in many regulatory functions throughout biochemical processes. But their roles in the development and inhibition of malignancies are complex. They have highlighted many alerts because of their essential roles and toxic effects at concentrations beyond those substantial for their biochemical functions [23].

$\mathrm{Se}$ is active in assorted types of selenoproteins as glutathione reductases, which plays an important role as antioxidant and in eliminating free radicals. Other selenoproteins have roles that sustain immune functions, and through specific cellular pathways may play a protective 


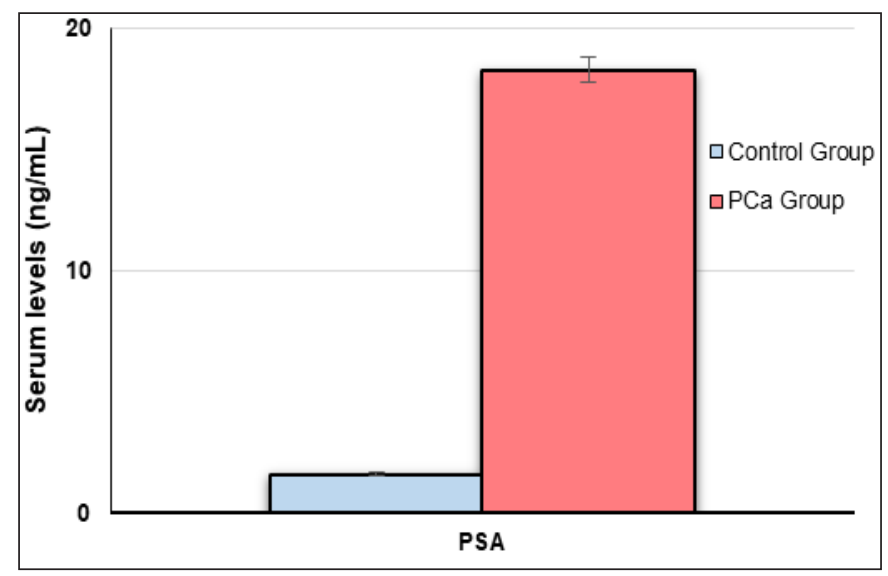

Fig. 1. Serum PSA levels in PCa and control groups.

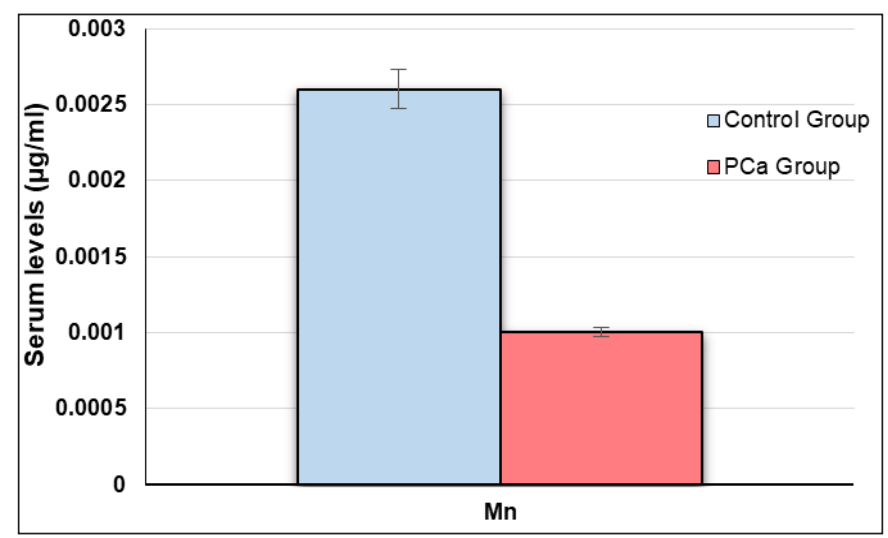

Fig. 3. Serum Mn concentrations in $\mathrm{PCa}$ and control groups.

role in both the initiation and promotion of certain malignancies. Thus, low Se levels may induce tumorigenesis [24]. Our results revealed that serum Se concentration was significantly lower in PCa patients as compared to $\mathrm{BPH}$ and healthy individuals. Many literatures indicated that low level of Se may correlate with carcinogenesis and is a risk factor of cancer. They showed a beneficial effect of high Se levels in the prevention of cancer and there were a clear antitumorigenic and chemo-preventive effects of Se in a variety of malignant tumors. In these cancers, erythrocyte, serum, and urine Se levels have been decreased compared to control groups [25].

Serum Trace Elements in Prostate Cancer

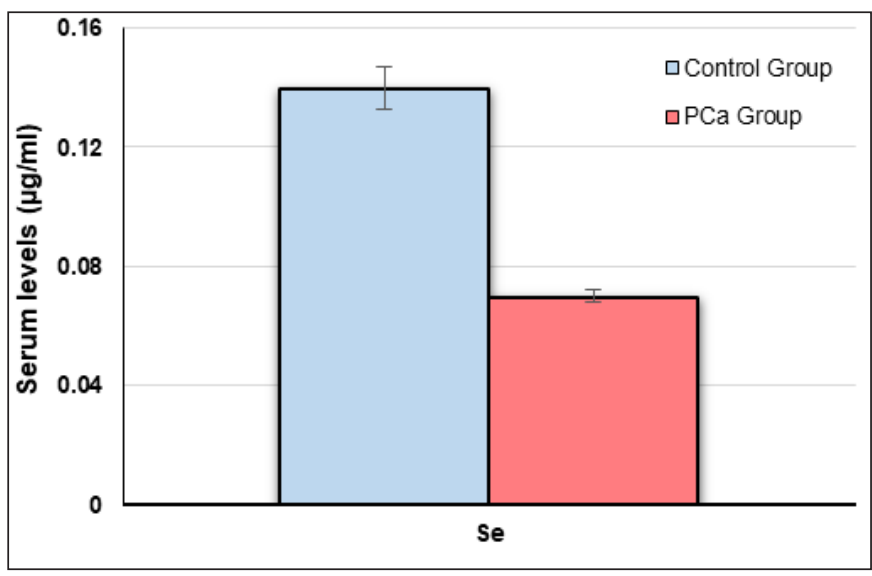

Fig. 2. Serum Se concentrations in $\mathrm{PCa}$ and control groups.

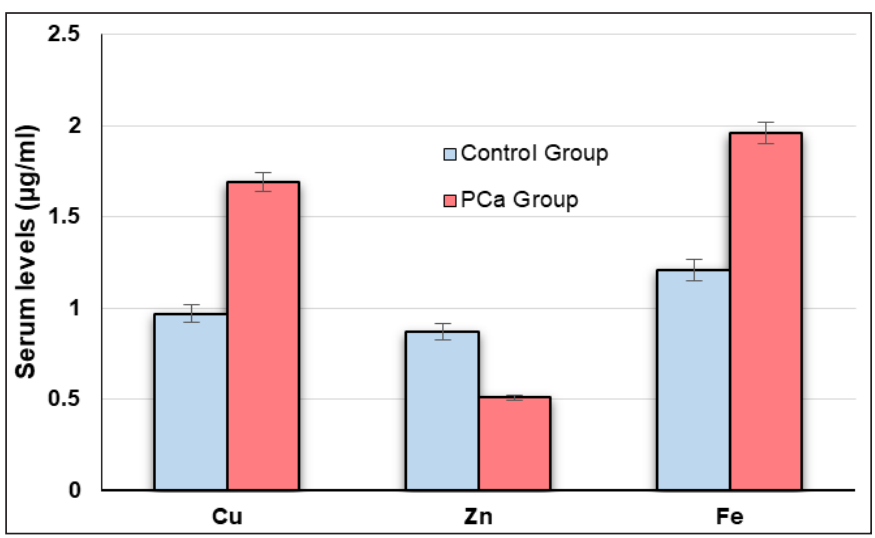

Fig. 4. Serum $\mathrm{Cu}, \mathrm{Zn}$ and $\mathrm{Fe}$ concentrations in $\mathrm{PCa}$ and control groups.

$\mathrm{Zn}$ is an essential element that has variety of functions and is required for many biochemical pathways. The human body contains $1.5-2.5 \mathrm{~g} \mathrm{Zn}$ in total, mostly found in bone, prostate, skin, skeletal muscle and retina. However, the regulation and function of $\mathrm{Zn}$ transporter proteins are still unclear. Plasma $\mathrm{Zn}$ is mostly bound to proteins such as albumin, macroglobulin and amino acids, and makes up only $0.1 \%$ of total $\mathrm{Zn}$ in the body [26]. The important role of $\mathrm{Zn}$ in immune function has been the subject of various studies [27]. In addition to its vital roles as co-factor for over 300 metalloenzymes, antioxidant and involvement in cellular signaling pathways, Zn plays vi- 
tal role as anti-carcinogen through its functions to stabilize DNA, RNA and ribosome as well as its involvement in cellular proliferation and differentiation [28]. Previous studies revealed that serum $\mathrm{Zn}$ concentrations were decreased in prostate, testicular, ovarian, cervical and bladder cancers [29-31], as well as Zn deficiency may increase the peril of $\mathrm{PCa}$ [32]. Our study indicated a marked decrease of serum $\mathrm{Zn}$ concentrations in the $\mathrm{PCa}$ patients compared to control individuals.

$\mathrm{Cu}$ as an essential trace element is involved in many biochemical processes as energy metabolism, iron homeostasis and antioxidant protection [33]. Serum $\mathrm{Cu}$ and ceruloplasmin concentrations increased in many cancers as leukemia, breast, cervix and endometrium cancers. $\mathrm{Cu}$, like $\mathrm{Zn}$, is an essential element for activation of DNA and RNA polymerase enzymes and has a role as co-factor for antioxidant enzymes [34]. $\mathrm{Zn}$ is recognized as a $\mathrm{Cu}$ antagonist, which may be resulted as observed hypozincemia with hypercupremia in malignant transformation. Due to the direct interference between intestinal absorption of $\mathrm{Zn}$ and $\mathrm{Cu}, \mathrm{Cu}$ could replace $\mathrm{Zn}$ binding with metallothionein, because of Cu's high affinity toward this protein [35]. This mechanism may explain the observed decrease of serum $\mathrm{Zn}$ concentration, which is accompanied with elevated serum $\mathrm{Cu}$ concentration measured in this study.

$\mathrm{Mn}$ is an essential element required for several metalloenzymes as pyruvate decarboxylase and superoxide dismutase that are concerned with energy production and antioxidant defense system [36]. Therefore, it can be suggested that decreased serum Mn concentrations may alter the antioxidant mechanism leading to target organs sensitive to carcinogens. Low serum Mn levels were reported in different urological cancer patients [37]. In the current study, we observed a significant difference in serum Mn levels of PCa patients compared to control groups. Mn has many chemical properties similar to Fe. Previous studies reported different metabolic interactions between $\mathrm{Fe}$ and $\mathrm{Mn}$, particularly through intestinal absorption [38].

While $\mathrm{Fe}$ is a vital trace element for normal cell functions, whose disturbance is associated with several diseases. A surplus of Fe may lead to an increased cell oxidative stress, resulting in accelerated tissue and DNA damage [39]. The present study indicated an elevated serum $\mathrm{Fe}$ concentration in $\mathrm{PCa}$ patients than in control groups. It has been demonstrated that the increased oxidative stress resulting from excess $\mathrm{Fe}$ may increase the risk of liver, pancreas and skin cancers [40], and many epidemiological researches indicated that low $\mathrm{Fe}$ concentrations could reduce cancer incidence including $\mathrm{PCa}$ $[41,42]$.

Our results revealed that serum trace element concentrations showed no statistical difference between BPH and healthy groups. Previous studies reported that the levels of these elements were not significantly different in BPH patients compared to control subjects and the slight disturbance of these trace elements could not involve in the etiology of BPH $[43,44]$.

\section{Conclusion}

In the present study, an association was noticed between trace elements disturbance and PCa. Furthermore, the decreased levels of $\mathrm{Se}, \mathrm{Zn}$ and $\mathrm{Mn}$ and increased $\mathrm{Cu}$ and $\mathrm{Fe}$ levels may play significant roles in the initiation of PCa. However, future prospective studies on the causes of trace elements alteration in PCa patients are needed. Further studies are needed to illustrate the relation between different $\mathrm{PCa}$ stages and trace elements concentrations.

\section{References}

1 American Cancer Society: Global Cancer Facts \& Figures 4th Edition. Atlanta, GA, USA. Available at: https://www.cancer.org/ research/cancer-facts-statistics.html. Accessed October 25, 2018.

2 Saudi Health Council Saudi Cancer Registry: Cancer Incidence Report Saudi Arabia 2014. Available at: https://nhic.gov.sa/eServices/ Documents/2014.pdf. Accessed December 2,2018 .
3 International Agency for Research on Cancer, World Health Organization: Global Cancer Observatory (GCO). Available at: http://gco. iarc.fr/tomorrow/home. Accessed December 10, 2018.

-4 Adedapo KS, Arinola OG, Shittu OB, Kareem OI, Okolo CA, Nwobi LN: Diagnostic value of lipids, total antioxidants, and trace metals in benign prostate hyperplasia and prostate cancer. Niger J Clin Pract 2012;15:293-297.
5 Ekman P, Pan Y, Li C, Dich J: Environmental and genetic factors: a possible link with prostate cancer. Br J Urol 1997;79(suppl 2): $35-41$.

6 Al-Hazzaa HM, Abahussain NA, Al-Sobayel HI, Qahwaji DM, Musaiger AO: Physical activity, sedentary behaviors and dietary habits among Saudi adolescents relative to age, gender and region. Int J Behav Nutr Phys Act 2011;8:140. 
$>7$ Bosetti C, Pelucchi C, La Vecchia C: Diet and cancer in Mediterranean countries: carbohydrates and fats. Public Health Nutr 2009, 12:1595-1600.

-8 Navarro Silvera SA, Rohan TE: Trace elements and cancer risk: a review of the epidemiologic evidence. Cancer Causes Control 2007;18:7-27.

>9 Yelinova V, Glazachev Y, Khramtsov V, Kudryashova L, Rykova V, Salganik R: Studies of human and rat blood under oxidative stress: changes in plasma thiol level, antioxidant enzyme activity, protein carbonyl content, and fluidity of erythrocyte membrane. Biochem Biophys Res Commun 1996;221:300-303.

10 Shukla VK, Adukia TK, Singh SP, Mishra $\mathrm{CP}$, Mishra RN: Micronutrients, antioxidants, and carcinoma of the gallbladder. J Surg On$\operatorname{col} 2003 ; 84: 31-35$.

$\checkmark 11$ Platz EA, Helzlsouer KJ: Selenium, zinc, and prostate cancer. Epidemiol Rev 2001;23:93101.

12 Smith ML, Lancia JK, Mercer TI, Ip C: Selenium compounds regulate $\mathrm{p} 53$ by common and distinctive mechanisms. Anticancer Res 2004;24:1401-1408.

$>13$ Etminan M, Fitzgerald JM, Gleave M, Chambers $\mathrm{K}$ : Intake of selenium in the prevention of prostate cancer: a systematic review and meta-analysis. Cancer Causes Control 2005; 16:1125-1131.

14 Mazdak H, Yazdekhasti F, Movahedian A, Mirkheshti N, Shafieian M: The comparative study of serum iron, copper, and zinc levels between bladder cancer patients and a control group. Int Urol Nephrol 2010;42:89-93.

-15 Faber M, Coudray C, Hida H, Mousseau M, Favier A: Lipid peroxidation products, and vitamin and status in patients with cancer before and after chemotherapy, including adriamycin. A preliminary study. Biol Trace Elem Res1995;47:117-123.

$>16$ Joazeiro CA, Weissman AM: RING finger proteins: mediators of ubiquitin ligase activity. Cell 2000;102:549-552.

$\checkmark 17$ Arredondo M, Nunez MT: Iron and copper metabolism. Mol Aspects Med 2005;26:313327.

18 Reddy MB, Clark L: Iron, oxidative stress, and disease risk. Nutr Rev 2004;62:120-124.

19 Althubiti MA, Nour Eldein MM: Trends in the incidence and mortality of cancer in Saudi Arabia. Saudi Med J 2018;39:1259-1262.
20 Patel AR, Klein EA: Risk factors for prostate cancer. Nat Clin Pract Urol 2009;6:87-95.

21 Dunn MW, Kazer MW: Prostate cancer overview. Semin Oncol Nurs 2011;27:241-250.

22 Hori S, Butler E, McLoughlin J: Prostate cancer and diet: food for thought? BJU Int 2011;107:1348-1359.

-23 Zowczak M, Iskra M, Torli ski L, Cofta S: Analysis of serum copper and zinc concentration in cancer patients. Biol Trace Elem Res 2001;82:1-8.

24 Behne D, Kyriakopoulos A: Mammalian selenium-containing proteins. Annu Rev Nutr 2001;21:453-473.

25 Li H, Stampfer MJ, Giovannucci EL, Morris JS, Willett WC, Gaziano JM, Ma J: A prospective study of plasma selenium levels and prostate cancer risk. J Natl Cancer Inst 2004; 96:696-703.

26 Maret W, Sandstead HH: Zinc requirements and the risks and benefits of zinc supplementation. J Trace Elem Med Bio 2006;20:3-18.

27 Fraker PJ, King LE: Reprogramming of the immune system during zinc deficiency. Annu Rev Nutr 2004;24:277-298.

28 Cousins RJ, Blanchard RK, Moore JB, Cui L, Green CL, Liuzzi JP, Cao J, Bobo JA: Regulation of zinc metabolism and genomic outcomes. JNutr2003;133(5 suppl 1):1521-1526.

29 Costello LC, Franklin RB: Zinc is decreased in prostate cancer: an established relationship of prostate cancer. J Biol Inorg Chem 2011; 16:3-8.

30 Saleh SK, Adly HM, Nassir AM: Altered trace elements levels in hair of prostate cancer patients. J Cancer Sci Ther 2017;9:336-339.

31 Yaman M, Kaya G, Simsek M: Comparison of trace element concentrations in cancerous and noncancerous human endometrial and ovary tissues. Int J Gynecol Cancer 2007; 17:220-228.

-32 Shahar S, Shafurah S, Hasan Shaari NS, Rajikan R, Rajab NF, Golkhalkhali B: Roles of dietary, lifetime physical activity and oxidative DNA damage in the occurrence of prostate cancer among men in Klang Valley, Malaysia. Asian Pac J Cancer Prev 2011; 12:605-611.

33 Sayır F, Kavak S, Meral I, Demir H, Cengiz N, Cobanoğlu U: Effects of crush and axotomy on oxidative stress and some trace element levels in phrenic nerve of rats. Brain Res Bull 2013;92:84-88.
34 Cunzhi H, Jiexian J, Xianwen Z, Jingang G, Shumin Z, Lili D: Serum and tissue level of six trace elements and copper/zinc ratio in patients with cervical cancer and uterine myoma. Biol Trace Elem Res 2003;94:113-122.

35 Milde D, Novák O, Stu ka V, Vyslou il K, Machá ek J: Serum levels of selenium, manganese, copper, and iron in colorectal cancer patients. Biol Trace Elem Res 2001;79:107114.

36 Johnson S: The possible crucial role of iron accumulation combined with low tryptophan, zinc and manganese in carcinogenesis. Med Hypotheses 2001;57:539-543.

37 Pirincci N, Gecit I, Gunes M, Kaba M, Tanik S, Yuksel MB, Arslan H, Demir H: Levels of serum trace elements in renal cell carcinoma cases. Asian Pac J Cancer Prev 2013;14:499_ 502.

38 Chua AC, Morgan EH: Effects of iron deficiency and iron overload on manganese uptake and deposition in the brain and other organs of the rat. Biol Trace Elem Res 1996;55:39-54.

-39 Ames BN: DNA damage from micronutrient deficiencies is likely to be a major cause of cancer. Mutat Res 2001;475:7-20.

40 Crawford RD: Proposed role for a combination of citric acid and ascorbic acid in the production of dietary iron overload: a fundamental cause of disease. Biochem Mol Med 1995;54:1-11.

41 Mainous AG 3rd, Wells BJ, Koopman RJ, Everett CJ, Gill JM: Iron, lipids, and risk of cancer in the Framingham Offspring cohort. Am J Epidemiol 2005;161:1115-1122.

42 Zacharski LR, Chow BK, Howes PS, Shamayeva G, Baron JA, Dalman RL, Malenka DJ, Ozaki CK, Lavori PW: Decreased cancer risk after iron reduction in patients with peripheral arterial disease: results from a randomized trial. J Natl Cancer Inst 2008;100:996-1002.

43 Zaichick S, Zaichick V: Prostatic Tissue Level of some Androgen Dependent and Independent Trace Elements in Patients with Benign Prostatic Hyperplasia. Androl Gynecol: Curr Res. 2015;3:3. doi:10.4172/23274360.1000141.

-44 Eken A, Ünlü-Endirlik B, Kaya E, Özgök Y, Erdem O, Akay C: Evaluation of trace element levels in patients with prostate cancer, benign prostatic hyperplasia and chronic prostatitis. Gülhane Tip Derg 2016;58:27-32. 